\title{
PENGEMBANGAN PERANGKAT PEMBELAJARAN MELALUI PENDEKATAN KONSTRUKTIVISTIK DENGAN METODE FIVE E (5E) STAGES LEARNING CYCLE UNTUK MENINGKATKAN HASIL BELAJAR DAN KETERAMPILAN PROSES SAINS
}

\author{
Mislan Sasono' ${ }^{1}$, Farida Huriawati ${ }^{2}$, Andista Candra Yusro ${ }^{3)}$ \\ ${ }^{1,2,3)}$ Program Studi Pendidikan Fisika, FKIP, Universitas PGRI Madiun, Indonesia
}

\begin{abstract}
Research aims to implement and develop the shape of the natural science/physics as device learning to enhance science process skills and the results oflearning through constructivist approach with (5E) stages of material objects and the learning cycle to its elementary school students of classes $V$. This research includes Research and Developmental research $(R \& D)$. In developing this form of learning devices used stage design (design), stage of development (develop), stages of dissemination (disseminate). The form of a learning device successfully developed by disseminaing once to three times, and subject learning classes $V$ at Kanigoro elementary school. Any form oflearning devices developed validated by researchers with triangulation. Activities undertaken by students and student learning outcomes during learning recorded as quantitative data and analyzed in qualitative descriptive. The shape of the device successfully developed through learning method 5E learning cycle stages was work Sheets, learning implementation plan, the evaluation sheet of the product. Based on the descriptive analysis of the obtained conclusions that the learning that has been developed successfully process skills increase students and student learning outcomes. Science process skills improvement students learning I, II, and III, i.e., 70.79\%, 73.97\%, as well as analysis results $78.10 \%$ average value of pre test and post test students experience increased i.e. 31 points from the average value of 33 pre test and average value of post test of 64 .
\end{abstract}

Keywords: Method Five E (5E) Learning Cycle, Results Learning, Science Process Skills

\begin{abstract}
Abstrak
Penelitian ini bertujuan menerapkan dan mengembangkan bentuk perangkat pembelajaran IPA/Fisika untuk meningkatkan keterampilan proses sains dan hasil belajar melalui pendekatan konstruktivistik dengan metode (5E) learning cycle materi benda dan sifatnya siswa SD kelas V. Penelitian ini termasuk penelitian Research and Developmental (R\&D). Dalam mengembangkan bentuk perangkat pembelajaran digunakan tahap perancangan (design), tahap pengembangan (develop), tahap penyebaran (d isseminate). Bentuk perangkat pembelajaran yang berhasil dikembangkan didiseminasikan satu kali untuk tiga kali pembelajaran, subjek penelitian siswa kelas V SD Kanigoro. Setiap bentuk perangkat pembelajaran yang dikembangkan divalidasi oleh peneliti dengan triangulasi. Aktivitas yang dilakukan oleh siswa dan hasil belajar siswa selama pembelajaran dicatat sebagai data kuantitatif dan dianalisis secara deskriptif kualitatif. Bentuk perangkat pembelajaran yang berhasil dikembangkan melalui metode 5E learning cycle adalah LKS, RPP, lembar evaluasi produk. Berdasarkan analisis deskriptif diperoleh kesimpulan bahwa perangkat pembelajaran yang telah dikembangkan berhasil meningkatakan keterampilan proses siswa dan hasil belajar siswa. Peningkatan keterampilan proses sains siswa setiap pembelajaran I, II, dan III yaitu $70.79 \%, 73.97 \%, 78.10 \%$ serta analisis hasil nilai rata-rata pre test dan post test siswa mengalami peningkatan yaitu 31 poin dari nilai rata-rata pretes sebesar 33 dan nilai rata-rata postes sebesar 64.
\end{abstract}

Kata Kunci: Metode Five E (5E) Learning Cycle, Hasil Belajar, Keterampilan Proses Sains

DOI : http:/dx.doi.org/10.21067/mpej.v1i1.1630

Diterima: Januari 2017; Disetujui: Maret 2017

\footnotetext{
* Corresponding Author:

mislan@unipma.ac.id
} 


\section{PENDAHULUAN}

Dinamika sosial dan politik yang berlangsung di Indonesia akhir-akhir ini turut mempengaruhi sektor pendidikan. Pergantian kekuasaan dari tangan ke tangan menyebabkan kebijakan-kebijakan yang diambilpun berganti dengan cepat. Kebijakan yang berkaitan dengan pendidikan direlisasikan dengan perubahan kurikulum sampai beberapa kali. Setiap perubahan pasti menginginkan terbentuknya kondisi ideal. Fisika sebagai salah satu bagian dari sains memiliki karakteristik ideal yang berbeda dengan bidang-bidang ilmu yang lainnya.

\section{Kurikulum}

Tingkat

Satuan

Pendidikan untuk mata pelajaran Ilmu Pengetahuan Alam untuk SD/MI khususnya Ilmu pengetahuan alam (IPA)/Fisika berkaitan dengan cara mencari tahu tentang alam secara sistematis, sehingga IPA/Fisika bukan hanya penguasaan kumpulan pengetahuan yang berupa fakta-fakta, konsep-konsep dan prinsip-prinsip saja tetapi juga merupakan suatu proses penemuan. Pendidikan IPA/Fisika diharapkan dapat menjadi wahana bagi peserta didik untuk mempelajari diri sendiri dan alam sekitar, serta prospek pengembangannya lebih lanjut dalam menerapkannya di dalam kehidupan sehari-hari. Sementara itu, menurut Trowbridge \& Bybee (1990:48) sains merupakan representasi dari suatu hubungan dinamis yang mencakup tiga faktor utama, yaitu: "the extant body of scientific knowledge, the values of science, and the methods and processes of science, yang memandang sains sebagai suatu proses dan metode (methods and processes) serta produk-produk (body of scientific knowledge), juga melihat bahwa sains mengandung nilai-nilai (values).

Para ilmuwan yang memahami sifatsifat sains melihat bahwa pengetahuan (knowledge) sebagai produk dari tindakantindakan ilmiah (scientific acts), mereka tidak melihat pengetahuan sebagai hakekat dari sains itu sendiri (science peer see). Oleh karena itu, mempelajari sains juga meliputi penjelajahan dan pengamatan melalui pertanyaan, rasa ingin tahu, formulasi pertanyaan, teka-teki dan penjelasan terhadap obyek, fenomena dan gagasan-gagasan, serta pada akhirnya bagaimana mengkomunikasikan gagasangagasan tersebut pada orang lain atau pada masyarakat. Sains sebagai proses/metode penyelidikan (inquiry methods) meliputi cara berpikir, sikap, dan langkah-langkah kegiatan saintis untuk memperoleh produkproduk sains atau ilmu pengetahuan ilmiah, misalnya observasi, pengukuran, merumuskan dan menguji hipotesis, 
mengumpulkan data, bereksperimen, dan prediksi.

Salah satu kompetensi dasar yang tercantum dalam KTSP mata pelajaran IPA/Fisika SD/MI kelas $\mathrm{V}$ semester 1 adalah mendeskripsikan hubungan antara sifat bahan dengan bahan penyusunnya. Berdasarkan panduan ini guru berhak mengembangkan sendiri materi-materi yang akan diajarkan pada siswanya. Kompetensi dasar ini pada dasarnya berhubungan erat dengan peristiwa yang dialami siswa dalam kehidupan sehari-hari. Oleh karena itu guru harus dapat mengembangkan suatu perangkat pembelajaran IPA/Fisika yang mampu menjelaskan hubungan antara sifat bahan dengan penyusunnya dan perubahan sifat benda sebagai hasil suatu proses kepada siswa agar dapat mengarahkan siswa melakukan keterampilan proses sains.

Pembelajaran IPA/Fisika yang dilakukan di SD lebih sering menggunakan metode ceramah dan sesekali demonstrasi. Hal ini menyebabkan siswa cenderung bersikap pasif dan tidak tertuntun pada proses berpikir ilmiah sebagaimana seharusnya. Dampak lain yang terjadi adalah rendahnya hasil belajar siswa karena ketertarikan siswa pada pelajaran IPA/Fisika sangat kurang. Pada dasarnya sarana pembelajaran IPA/Fisika yang ada di SD sudah cukup memadai. Laboratorium
IPA/Fisika dengan peralatan yang cukup lengkap tersedia disana hanya saja penggunaannya kurang dioptimalkan dengan baik. Melihat kenyataan seperti ini sudah selayaknya guru lebih kreatif mengatasi permasalahan dengan mengembangkan perangkat pembelajaran yang paling sesuai dengan memanfaatkan bahan yang mudah diperoleh dalam kehidupan sehari-hari.

Sebuah solusi yang bisa ditawarkan atas masalah di atas, yaitu dengan menyiapkan siswa menjadi anak yang adaptif. Kegiatan pembelajaran dengan pendekatan konstruktivistik, mengajar bukanlah kegiatan memindahkan pengetahuan dari guru ke murid, melainkan suatu kegiatan yang memungkinkan membangun sendiri pengetahuannya.

\section{METODE}

Penelitian ini bertujuan untuk mengembangkan perangkat pembelajaran IPA/Fisika dengan Orientasi pendekatan konstruktivistik melalui metode (5E) learning cycle dalam pembelajaran kooperatif IPA/Fisika di SD. Berdasarkan tujuan penelitian tersebut maka penelitian ini termasuk kedalam penelitian Research and Development (R\&D). Adapun desain penelitian yang digunakan dalam penelitian ini adalah penelitian pengembangan model 4-D (Four-D Models). 
Perangkat pembelajaran hasil dari mendefinisikan kebutuhan-kebutuhan pengembangan tersebut kemudian didalam proses pembelajaran. digunakan sebagai perangkat 2. Tahap Perencanaan (Design)

pembelajaran. Perangkat tersebut Tujuan dari tahap ini adalah untuk diterapkan ke dalam setiap komponen merancang suatu bentuk perangkat pembelajaran dengan mengembangkan pembelajaran, untuk memulai tahap media pembelajaran IPA/Fisika yang perencanaan ini sebelumnya disusun melatih keterampilan proses sains dengan serangkaian tujuan pembelajaran khusus pendekatan konstruktivistik dengan terlebih dahulu, dan selanjutnya dilakukan metode (5E) learning cycle dan perangkat pemilihan media atau format untuk pembelajaran yang dikembangkan meliputi perangkat pembelajaran.

Rencana Pelaksanaan Pembelajaran, 3. Tahap Pengembangan (Develop)

Lembar Kegiatan Siswa, dan Tes Hasil Pada tahap ini contoh model belajar.

\section{A. Tahap - tahap Pengembangan}

perangkat pembelajaran yang akan Perangkat Pembelajaran

Perangkat pembelajaran yang digunakan kemudian dikembangkan. Untuk mengembangkan perangkat dikembangkan meliputi: Rencana Pelaksanaan Pembelajaran (RPP), Lembar Kegiatan Siswa (LKS) dan lembar evaluasi produk.

Adapun pengembangan perangkat menggunakan model 4-D yang terdiri dari tahap pendefinisian (define), tahap pembelajaran ini, peneliti secara intensif berkonsultasi dengan guru kelas dimaksudkan untuk memperoleh saran terkait dengan perangkat pembelajaran. Hasil revisi di uji cobakan dalam pembelajaran yang selanjutnya akan dilakukan tahap penyebaranluasan.

$\begin{array}{lcc}\text { perencanaan } & \text { (design), } & \text { tahap } \\ \text { pemgembangan } & \text { (develop), dan } & \text { tahap }\end{array}$

4. Tahap Penyebaran luasan pemgembangan (develop), dan tahap (Disseminate)

pendisseminisian (disseminate)

Tujuan dari tahap ini adalah (Thiagarajan, Semmel : 1974). Deskripsi pembelajaran di kelas sesungguhnya dari masing-masing tahap adalah sebagai (sekolah). Melalui tahap desiminasi ini berikut :

\section{Tahap Pendefinisian (Define)} akan diperoleh kelayakan perangkat Tujuan dari tahap pendefinisian digunakan didalam proses pembelajaran. adalah untuk menetapkan dan 
B. Perangkat Pembelajaran yang

dikembangkan

Perangkat pembelajaran yang dikembangkan berdasarkan empat tahap seperti yang diuraikan di atas terdiri dari : Rencana Pelaksanaan Pembelajaran (RPP), Lembar Kegiatan Siswa (LKS), Lembar Evaluasi Produk.

C. Subjek Penelitian

Subjek penelitian diambil di SD Kanigoro siswa kelas $\mathrm{V}$, pengembangan perangkat pembelajaran dilakukan pada subjek penelitian dalam beberapa tahap sesuai dengan materi pelajaran atau pokok bahasan yang disampaikan dan tujuan yang akan dicapai.

D. Pelaksanaan Tahap-tahap

Pengembangan

Perangkat pembelajaran yang dikembangkan meliputi: Rencana Pelaksanaan Pembelajaran (RPP), Lembar Kegiatan Siswa yang dikembangkan dengan subpokok bahasan yang dipelajari dengan menyesuaikan dengan materi, serta lembar evaluasi produk. Kegiatan yang dilakukan oleh setiap siswa dalam setiap tahap adalah diskusi kelompok, praktikum, penemuan konsep, penarikan kesimpulan dan evaluasi. Pada setiap akhir tahap pengembangan diadakan diskusi/evaluasi oleh peneliti dan pengamat (observer) terhadap pembelajaran yang sudah dilakukan.

\section{E. Instrumen dan Teknik Pengambilan Data}

Untuk mengevaluasi dan memonitor pada setiap tahapan pengembangan digunakan lembar observasi antara lain:
1) Lembar
observasi
pengelolaan pembelajaran oleh guru
2) Lembar observasi aktivitas antara guru dan siswa

Reliabilitas instrumen lembar observasi aktivitas siswa dan guru serta pengelolaan guru dalam pembelajaran diukur dengan teknik inter observer agreement, yaitu Instrumen dikatakan reliabel menurut Borich dalam (Insih Wilujeng, 1999:76), jika nilai reliabilitas diperoleh $\geq 0.75$. Untuk mencari reliabilitas instrumen menurut Grinnel dalam (Insih Wilujeng, 1999: 77) dapat ditentukan menggunakan:

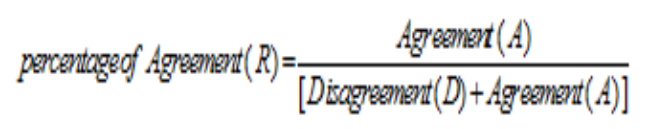

\section{F. Teknik Analisis Data}

Analisis data dalam penelitian ini dimaksudkan untuk menjawab permasalahan dalam rangka merumuskan suatu kesimpulan. Analisis data menggunakan statistik deskriptif, adapun analisa data dalam penelitian ini adalah sebagai berikut:

1. Analisis Deskriptif Aktivitas Siswa dan Guru dalam Pembelajaran 
Untuk melakukan analisis deskriptif pengembangan (develop), dan tahap aktivitas siswa dan guru dalam disseminasi (disseminate) (Thiagarajan, pembelajaran dalam pembelajaran IPA, Semmel, 1974: 5). Hasil temuan pada maka analisis deskriptif yang dilakukan masing-masing tahap penelitian tersebut, menggunakanan presentase (\%) yaitu dapat dijelaskan sebagai berikut: banyaknya frekuansi aktivitas yang muncul 1. Tahap Pendefinisian (Define) dibagi seluruh frekuansi aktivitas dikalikan $100 \%$.

\section{Analisis \\ Deskriptif \\ Lembar}

Pengelolaan Guru dalam Pembelajaran

Untuk melakukan analisis deskriptif lembar pengelolaan guru, maka analisis deskriptif yang dilakukan menurut Wilujeng (1999: 87-88) menggunakan ketentuan sebagai berikut:

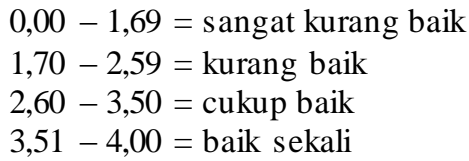

\section{Keberhasilan Produk}

Untuk mengetahui keberhasilan produk yang berupa pemahaman siswa mengenai materi yang diberikan dapat ditentukan dengan melihat dan menganalisis hasil penulisan konsep yang ditemukan oleh siswa pada LKS. Secara matematis dapat dituliskan sebagai berikut:

keterangan :

$$
\% \mathrm{KP}=(\mathrm{X} / \mathrm{N}) \times 100 \%
$$

$\% \mathrm{KP}=$ Presentase keberhasilan produk

$\mathrm{X} 1=$ Sis wa menjawab benar

$\mathrm{X} 2=$ Siswa menjawab salah

$\mathrm{N} \quad=$ Jumlah Siswa

\section{HASIL DAN PEMBAHASAN}

Penelitian ini telah dilakukan dalam 4 tahap, yaitu pendefinisian (define), tahap perancangan (design), tahap observasi ke sekolah dan melakukan guru bidang studi IPA mengenai pembelajaran yang dilaksanakan di SD Negeri Kanigoro meliputi: 1) model

Penelitian diawali dengan melakukan penjaringan-penjaringan informasi dengan pembelajaran, 2) pemanfaatan media pembelajaran dan 3) hasil belajar siswa.

2. Tahap Perancangan (Design)

Sesuai dari hasil pendefinisian (define) yang sudah dilakukan atau diperoleh, selanjutnya dilakukan tahap perancangan (design). Pada tahap perancangan (design) dilakukan pemilihan perangkat pembelajaran serta format pembelajaran yang akan dikembangkan antara lain perancangan Lembar Kegiatan Siswa (LKS), Perancangan Rencana Pelaksanaan Pembelajaran (RPP) serta lembar evaluasi produk., khususnya pada pokok bahasan benda dan sifatnya yang sesuai dengan tahap pendefinisian (define) sebagai observasi awal dan analisis kebutuhan yang ada di SD Negeri Kanigoro.

3. Tahap Pengembangan Perangkat Pembelajaran (Develop) 
Kegiatan pengembangan perangkat pembelajaran dengan mengadopsi model pengembangan melalui Pengembangan model 4-D (Four-D Models) telah berhasil mengembangkan perangkat pembelajaran yang diperlukan dalam proses pembelajaran IPA pokok bahasan "benda dan sifatnya" pada SD Negeri Kanigoro. Perangkat pembelajaran yang berhasil dikembangkan adalah; (1) Rencana Pelaksanaan Pembelajaran (RPP), (2) Lembar Kegiatan Siswa (LKS), dan (3) Lembar evaluasi produk.

\section{a. Rencana Pelaksanaan Pembelajaran (RPP)}

Rencana Pelaksanaan Pembelajaran (RPP) merupakan pedoman yang dirancang secara sistematis, dikembangkan untuk menggambarkan skenario penyajian materi pelajaran sesuai dengan sintaks model pembelajaran.

Tabel 1. Validasi Rencana Pelaksanaan Pembelajaran

\begin{tabular}{|c|c|}
\hline $\begin{array}{l}\text { Sumber } \\
\text { revisi }\end{array}$ & Jenis revisi / saran \\
\hline $\begin{array}{l}\text { Validasi } \\
\text { ahli }\end{array}$ & 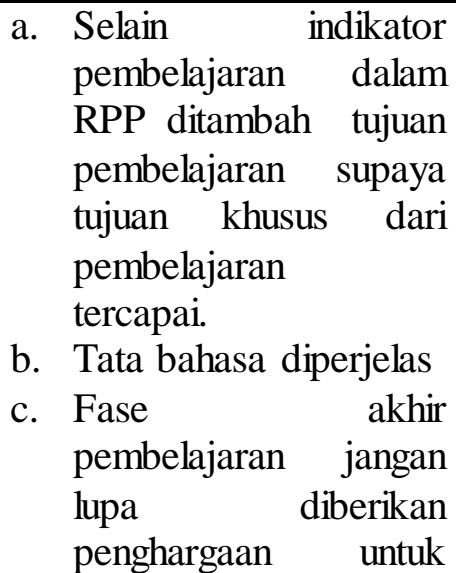 \\
\hline
\end{tabular}

\begin{tabular}{ll}
\hline kelompok yang \\
bekerja sungguh- \\
sungguh supaya di \\
setiap pembelajaran \\
berikutnya motivasi \\
siswa meningkat \\
\hline
\end{tabular}

\section{b. Lembar Kegiatan Siswa (LKS)}

Lembar kegiatan siswa merupakan lembar panduan bagi siswa dalam mengerjakan tugas secara kelompok yang berorientasi pada model pembelajaran kooperatif tipe STAD. Hasil revisi LKS selama pengembangan, secara ringkas dapat dilihat pada Tabel 2. berikut:

\section{Tabel 2. Validasi Lembar Kegiatan} Sis wa

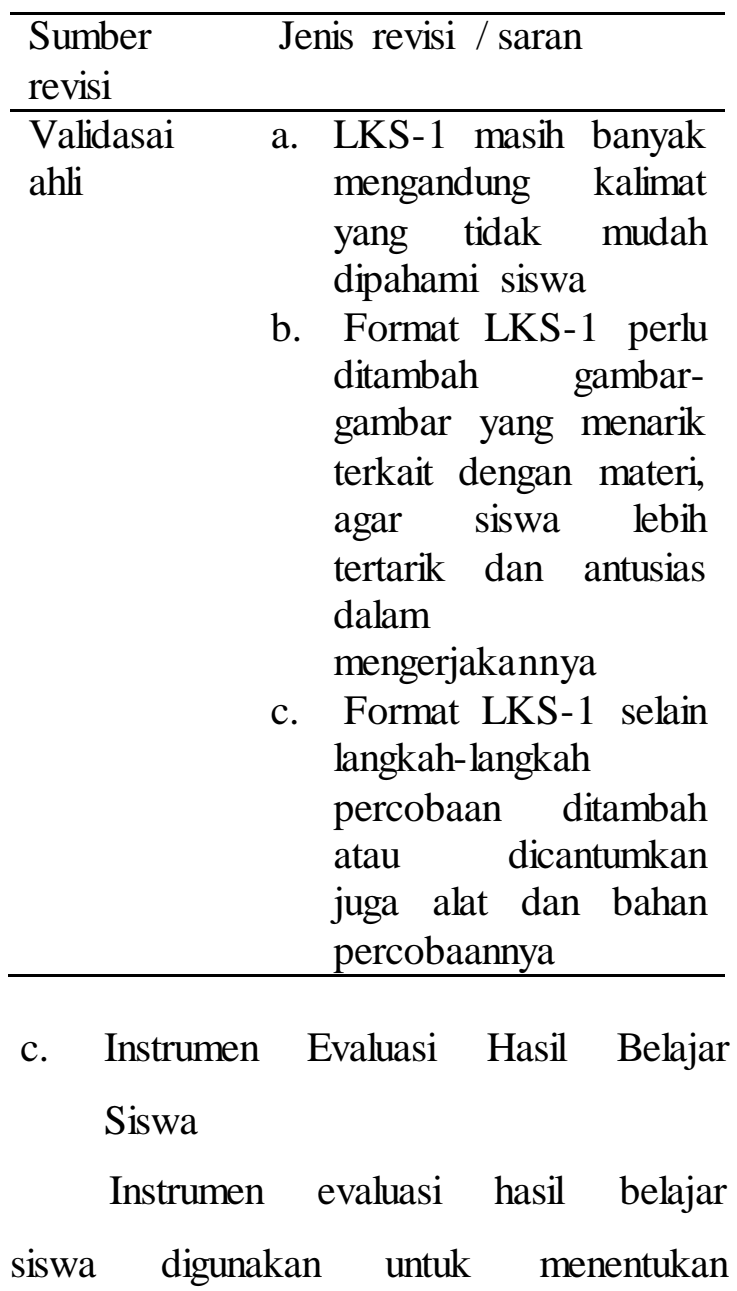


kualitas hasil belajar siswa. Instrumen evaluasi hasil belajar berupa perangkat soal tes hasil belajar. Tes hasil belajar yang dikembangkan adalah pretest-postest.

4. Tahap Ujicoba Terbatas (Disseminate)

Pelaksanaan penelitian penerapan perangkat pembelajaran pokok bahasan benda dan sifatnya yang telah dikembangkan oleh peneliti, telah dilaksanakan pada siswa kelas V SD Kanigoro yang berjumlah 30 Siswa. Hasil observasi masing-masing disajikan sebagai berikut:

\section{a. Keterampilan Proses Siswa dan Hasil Belajar Siswa}

Koefisien reliabilitas Instrumen aktivitas guru dan siswa dalam pembelajaran secara ringkas dapat disajikan pada Tabel 3. berikut:

Tabel 3. Perhitungan Koefisien Reliabilitas Lembar Keterampilan proses Siswa Disetiap Pertemuaan (RPP)

\begin{tabular}{cc}
\hline $\begin{array}{c}\text { Pertemuan pada } \\
\text { setiap RPP }\end{array}$ & $\begin{array}{c}\text { Prosentase } \\
\%\end{array}$ \\
\hline I & 62,5 \\
\hline II & 71,43 \\
\hline III & 85,71 \\
\hline
\end{tabular}

Sedangkan untuk keterampilan proses siswa dalam pembelajaran sebagai berikut:

Tabel 4. Prosentase Keterampilan Proses Siswa Disetiap Pertemuaan (RPP)

\begin{tabular}{cc}
\hline & Prosentase \\
$\begin{array}{c}\text { Pertemuan pada } \\
\text { setiap RPP }\end{array}$ & Keterampilan Proses \\
& Siswa \\
$\%$ \\
\hline I & 70,79 \\
\hline II & 73,97 \\
\hline III & 78,10 \\
\hline
\end{tabular}

\section{b. Keberhasilan Produk}

Keberhasilan produk ini dapat dilihat dari hasil nilai rata-rata pre-test dan posttest dapat dilihat pada Tabel 5.

Tabel 5. Deskripsi Data Tentang Nilai Rata Rata Kelas dari Hasil Pre-Test Dan Post-Test yang Dilakukan

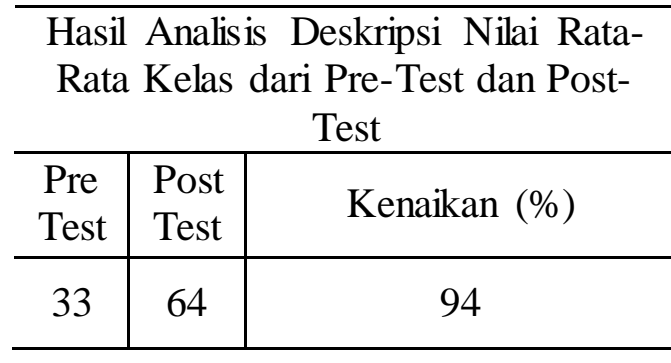

Pada dasarnya, penelitian ini dilakukan dalam 4 tahap, yaitu pendefinisian (define), tahap perancangan (design), tahap pengembangan (develop), dan tahap diseminasi (disseminate). Tujuan dari penelitian ini adalah mengembangkan bentuk perangkat pembelajaran yang menekankan pada model pembelajaran kooperatif dengan RPP didesain dengan 5E. Firdaus (2016) respon siswa terhadap pembelajaran merupakan sikap siswa terhadap pembelajaran berorientasi pada siklus belajar 5E yang telah dilaksanakan. Terdapat beberapa siswa yang memberikan responnya secara tidak konsisten, tetapi 
secara umum, siswa menyatakan bahwa pembelajaran siklus belajar $5 \mathrm{E}$ merupakan pembelajaran yang baru bagi siswa, dapat melatih keterampilan berpikir dan membantu memahami materi pelajaran yang dipelajarinya, serta dapat meningkatkan kemandirian belajar siswa.

Adapun pembahasan dari masingmasing data hasil penelitian adalah sebagai berikut:

\section{Pelaksanaan Diseminasi Perangkat Pembelajaran \\ Pelaksanaan diseminasi dimulai} setelah terdapat kesepakatan antara peneliti dan guru mata pelajaran. Diseminasi dilakukan melalui pengembangkan perangkat pembelajaran pada pembelajaran kooperatif tipe STAD yang dilakukan selama tiga kali pertemuan (3 RPP) dengan sub materi masing-masing adalah (1) RPP1 dengan pokok bahasan benda dan sifatnya pada sub pokok bahasan bahan penyusun benda, (2) RPP-2 dengan pokok bahasan benda dan sifatnya pada sub pokok bahasan sifat jenis bahan, dan (3) RPP-3 dengan sub pokok bahasan sifat kekuatan bahan serta perubahan benda.

Dalam pembelajaran ini siswa melakukan serangkaian kegiatan seperti yang terdapat pada lembar kegiatan siswa, setiap aktivitas keterampilan proses siswa yang dilakukan selalu diamati oleh pengamat. Hasil belajar siswa diukur lewat pengerjaan soal pre dan post tes sedangkan peningkatan hasil belajar siswa dilihat dari hasil pre-tes dan pos tes yang dilaksanakan 2 kali sebelum pertemuan I dan akhir dari pembelajaran pada pertemuan III dengan melakukan pos-tes. Setiap Kelompok juga diberikan penghargaan untuk kelompok terbaik pada akhir pembelajaran setelah semua kelompok mempresentasikan hasil pekerjaannya di depan kelompok lain, hal ini dilakukan sebagai pemotivasi siswa pada pembelajaran berikutnya. Hasil penelitian Astutik (2012) menunjukkan bahwa siswa tertarik mengikuti pembelajaran dengan menggunakan 5E, dan siswa sangat antusias dalam menjawab pertanyaan-pertanyaan dari guru.

Permasalahan yang terjadi pada diseminasi adalah guru kurang mampu dalam mengalokasikan waktu, hal ini terlihat dari penilaian pengelolaan pembelajaran bahwa dalam alokasi waktu evaluasi dan penutup masih kurang..

Berdasarkan hasil analisis deskriptif data pengamatan keterampilan proses siswa mengalami peningkatan disetiap pembelajaran I, II dan III terlihat dari hasil koefisien reliabilitas instrumen secara berturut-turut adalah 62,50\%, 71,93\%, dan $85,71 \%$. serta keterampilan proses siswa yang muncul dalam pembelajaran pada pembelajaran I, II, III adalah 70,79\%, $73,97 \%, \quad 78,10 \%$ sehingga dapat disimpulkan bahwa keterampilan proses 
siswa mengalami peningkatan setiap pertemuan yang dilakukan.

2. Deskripsi Keberhasilan Produk

Keberhasilan produk ini dapat dilihat dari hasil nilai rata-rata pre-test dan posttest kelas yang dilakukan 2 kali yaitu diawal yaitu sebelum dilakukan pelaksanaan RPP pertama serta diakhir pembelajaran pada pertemuan ketiga. Ratarata nilai pre-test yang dilakukan dari pengerjakaan lembar evaluasi hasil belajar adalah 33 dan nilai rata-rata post-test adalah 64 .

Berdasarkan hasil dari pembelajaran I, I, dan III diperoleh pengertian bahwa pengembangan perangkat pembelajaran melalui pendekatan konstruktivistik dengan Metode Five E (5E) pokok bahasan benda dan sifatnya dalam pembelajaran ternyata pembelajaran III lebih baik dibandingkan dengan pembelajaran I dan II. Indikasi ini dapat dilihat dari nilai ratarata pengerjaan pre dan post tes.

\section{SIMPULAN}

Berdasarkan analisis deskriptif data penelitian dari diskusi hasil penelitian dapat disimpulkan bahwa :

1. Bentuk perangkat pembelajaran yang berhasil dikembangkan dengan metode five $\mathrm{E}$ (5E) learning cycle untuk keterampilan proses sains dengan pendekatan konstruktivistik pada pokok bahasan benda dan sifatnya sebagai media pembelajaran IPA ada 3 yaitu RPP, LKS dan Tes Evaluasi Hasil Belajar. Dan keterampilan proses sains siswa mengalami peningkatan pada setiap pembelajaran I, II, dan III yaitu $70,79 \%, 73,97 \%, 78,10 \%$.

2. Bentuk perangkat pembelajaran yang dikembangkan dengan metode 5E pada pokok bahasan benda dan sifatnya mampu meningkatkan hasil belajar siswa kelas V SD Negeri Kanigoro, analisis hasil nilai rata-rata pre-test dan post-test siswa mengalami peningkatan yaitu 31 poin dari nilai rata-rata pretes sebesar 33 dan nilai rata-rata postes sebesar 64.

\section{DAFTAR RUJUKAN}

Astutik, S. (2012). Meningkatkan Hasil Belajar Siswa Dengan Model Siklus Belajar (Learning Cycle 5E) Berbasis Eksperimen Pada Pembelajaran Sains Di SDN Patrang I Jember. Jurnal Ilmu Pendidikan Sekolah Dasar, 1(2), 143-153.

Firdaus, L., Ibrahim, M., \& Agustini, R. (2016). Pengembangan Perangkat Pembelajaran Sains Berorientasi Pada Siklus Belajar 5E Untuk Memberdayakan Keterampilan Berpikir Dan Pemahaman Konsep 
Siswa SMP. Bioscientist: Jurnal

Ilmiah Biologi, 2(1).

Wilujeng, I. (1999) "Penerapan

pendekatan Reciprocal Teaching (

Pengajaran Balik) dalam

Pembelajaran Fisika (IPBA) SMU

pada Pokok Bahasan Tektonik

Lempeng". Tesis. Universitas Negeri

Surabaya.

Thiagarajan. S, Semmel. Ds, \& Semmel

M.I. (1974). Instructional

Development for Training Teachers

of Exceptional Chlidren. Minnepolis:

Indiana University.

Trowbridge, L.W. \& Bybee, R.W., (1990),

Becoming A Secondary School

Science Teacher. Columbus: Merrill

Publishing Co., A Bell \& Howell

Information Co. 